\title{
Noha Alghamdi translates Rupi Kaur
}

it has been one of the greatest and most difficult years of my life. I learned everything is temporary. moments. feelings. people. flowers. I learned love is about giving- everything- and letting it hurt. I learned vulnerability is always the right choice because it is easy to be cold in a world that makes it so very difficult to remain soft. I learned all things come in twos: life and death, pain and joy, sugar and salt, me and you. it is the balance of the universe. it has been the year of hurting so bad but living so good, making friends out of strangers, making strangers out of friends, learning mint chocolate chip ice- cream will fix just about everything and for the pains it can't, there will always be my mother's arms. We must learn to focus on warm energy, always. soak our limbs in it and become better lovers to the world, for if we can't learn to be kinder to each other how will we ever learn to be kinder to the most desperate parts of ourselves.

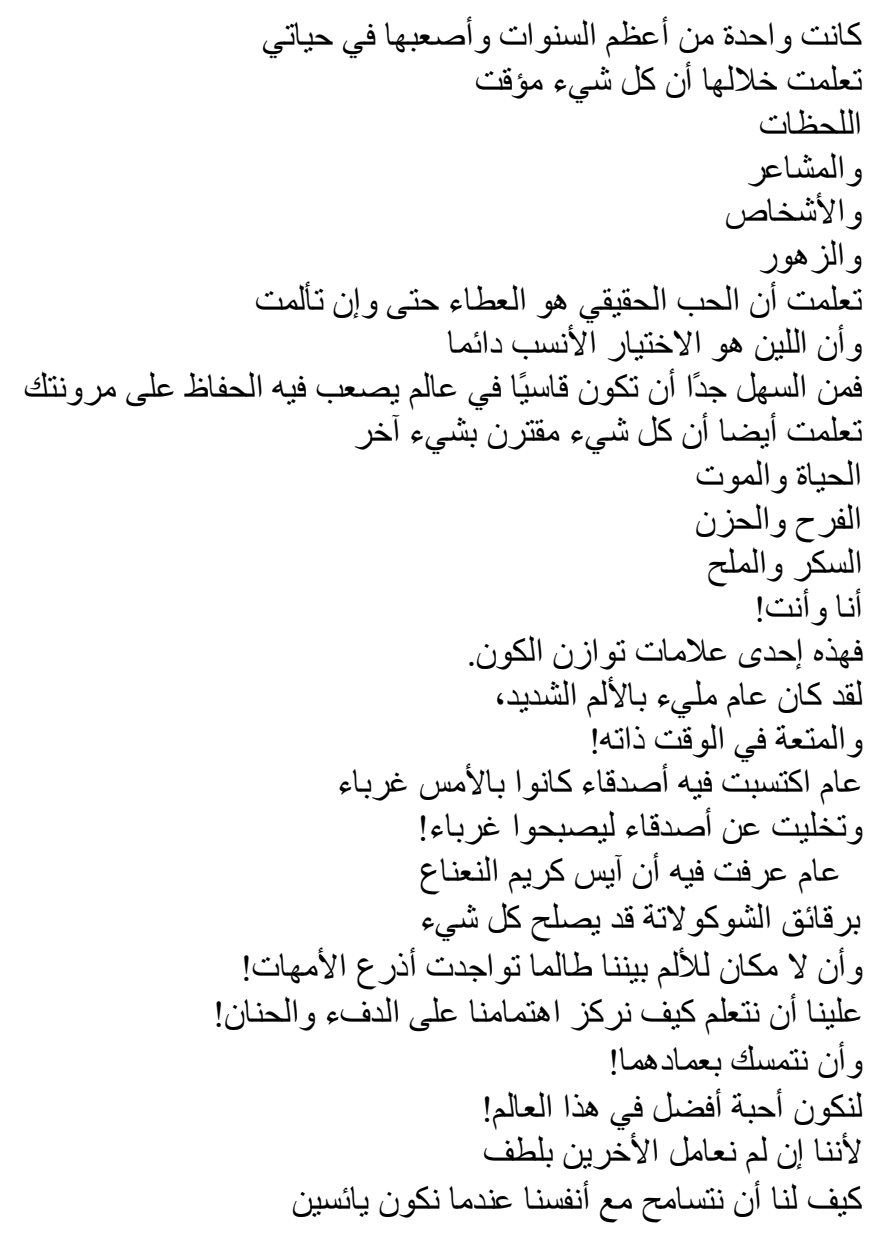


they have no idea what it is like

to lose home at the risk of

never finding home again

to have your entire life

split between two lands and

become the bridge between two countries

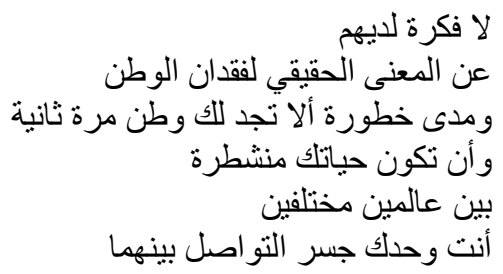

I am sorry this world

could not keep you safe

may your journey home

be a soft and peaceful one

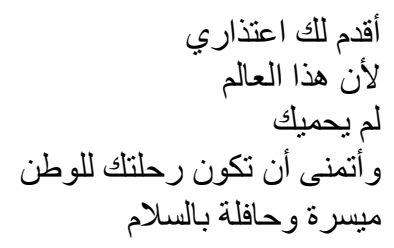

Loneliness is a sign you are in desperate need of yourself

وما الوحدة سوى مؤشرٌ على أنكَ في حاجة ماسة إلى ذاتكا

you might not have been my first love

but you were the love that made

all other loves seem

irrelevant

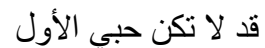

لكنك الحب الذي جعل كل حب آلَ آخر

لا يهم 
Let it go

let it leave

let it happen

nothing

in this world

was promised or

belonged to you

anyway

$$
\begin{aligned}
& \text { فلتنس الـأمر } \\
& \text { وتمض قدما } \\
& \text { فلا شيء في هذا العالم } \\
& \text { مُقدر أن يكون ملكك للأبد! }
\end{aligned}
$$

